\title{
RESEARCHARTICLE
}

\section{Communicating Gender, Race and Nation in the Purvi Patel case: The State, Biopower, and the Globality of Reproductive Surveillance}

\author{
Priya Kapoor
}

Department of International and Global Studies, Portland State University, Portland, Oregon 97201, USA

Because it is only when we hold this critical, resistant multiraciality that we will be able to see in sharp pixels - despite the ache in our souls - the truth of Purvi's conviction as the tragic tale of a society that cared more about its sociopolitical boundaries than the honor, humanity and dignity of a mother, her loss, and her lost mixed-race child.(Blogger Susan Chang, 2015)

I do not believe that just because you're opposed to abortion, that that makes you prolife. In fact, I think in many cases, your morality is deeply lacking if all you want is a child born but not a child fed, not a child educated, not a child housed. And why would I think that you don't? Because you don't want any tax money to go there. That's not pro-life. That's pro-birth. We need a much broader conversation on what the morality of pro-life is.(Sister Joan Chitister quoted by Salzillo, 2015)

Purvi Patel was bleeding after a miscarriage when she drove herself to the local hospital in South Bend on the night of July 13-14, 2013. She hid the lifeless fetus behind the family restaurant she worked in (Gray, 2015; Bazelton, 2015). Despite the precarity of her postpartum condition, with a twenty percent loss of blood, Patel was incarcerated after being subject to questioning by County Metro Homicide Unit Detective Galen Pelletier, a few hours after she checked in at the emergency unit. Patel's pleas of miscarrying were not heeded so she was treated as if she had executed a premeditated abortion. Patel was convicted on two counts of 1) feticide, in keeping with Indiana state laws at the time, and more controversially 2) of child neglect and endangerment. Patel became the only woman in U.S. history to be convicted with a twenty-year sentence for feticide. National media did a one-time coverage of Purvi Patel's' case warning readers about this apparent injustice and how it would change the interpretation of reproductive health law in the US (McCarter, 2018; Bazelton, 2015). More importantly, Patel's conviction would provide dangerous precedence for abortion as a crime for which the woman can get a lengthy sentence of two or three decades. "The law stands to be perverted to entrap a woman rather than protect her pregnancy from harm by an abusive partner.

While key national dailies covered the incident, it was the blogosphere that provided a critical public arena with rich commentary to fulfil the citizen's role in a deliberative democracy. In a time when advocates of the digital divide beg for net neutrality, examining blogs is especially important (Eckert, 2018; Duffy, 2015; Fraser, 2007). Therefore, I have chosen to analyze three significant blogs from 2015, chosen because Purvi Patel's case was being tried and convicted in Governor Mike Pence's Indiana. And secondly, I examine Reproductive Health and its variants Population Control and Eugenics as transnational discourse(s) in the age of globalization. I use case studies of China, India, and the US to demonstrate how biopolitical control of women's bodies by the state constitutes vital policy design in the service of national development and progress (Stoler, 2010).

Given the facts of the case, this study poses the question-are we better off for these national and global efforts toward curbing, curtailing, and controlling women, their reproduction and their bodies (see endnote on ICPD, Cairo). Additionally, one must remain attentive to linkages made between curtailment of reproductive rights and 'good works' that are easy to state such as alleviating poverty, preserving life etc. Another reason for attentiveness is if fertility control events are seen as just history and not continuous with the present (Kristof, 2008).

The transnational displacements that Purvi Patel and her family have undergone make 
them subjects of a complex, global history and diaspora that has not found acceptance ${ }^{\mathrm{iii}}$ as worthy citizens in their adoptive home in South Bend, Indiana. Secondly, bloggers selected for this study have made strong connections to events, themes and metaphors, juxtaposing global events ${ }^{\text {iv }}$ impacting gender construction and misogyny transnationally, and the treatment of Purvi Patel in Indiana. To scrutinize the bloggers interpretation of Purvi Patel's fate, and the connections they have made by bridging the gaps in her (East/West subaltern) identity, and for the easy slippage allowed in the execution of a law meant to provide justice to pregnant women. I examine the Purvi Patel saga as a case with deep historical and cultural links with the family planning policies of India and China for which the US remained a model (Lombardo, 2003; Connelly, 2003; Connelly, 2006).

An excerpt of Blogger Chang's (2015) post serves as an important epigraph for this essay. Chang densely packs important themes that motivate the study, namely resistant multiraciality in modern societies, the crossing of metaphorical borders or boundaries when it comes to issues of race, and gender. ${ }^{v}$ The second epigraph is a bold statement by a prolifeCatholic nun, Sister Joan Chitister, who reveals the misogyny in politicized Pro-Life positions that seem incredibly mean spirited toward women and their bodies. She also reveals certain false dichotomies between pro-life and pro-choice positions. Both epigraphs set the tone of the study to which I have been drawn to study biopoliticized diktats by the state curbing women's autonomy in matters of reproduction. The national and the transnational are bound together by global politics (Kapoor, 2016; Tomlinson, 1994): the foreign policies of powerful nations such as the United States, and nation-building exercises of postcolonial nations such as India and China. I also weave through the conventions of social science method that seeks to disregard certain narratives which seem anecdotal and media-generated (like blogs), or minority ethnic media with limited circulation (Asian American press like India Abroad, News India-Times, etc.) and embrace data gathering methods that are statistical and measurable. To make connections between methodology and popular culture narratives often amounts to flouting convention and abandoning rigor.

The immediate trigger for this conversation on reproductive health politics, is Purvi Patel. I am referring to the quiet unease among the South Asian and Asian community in the US, when Purvi Patel was awarded the life imprisonment sentence. She is alleged to have taken abortion-inducing drugs to end her pregnancy. Press reports indicate that the OB-GYN emergency room doctor, a pro-lifer, contacted the police, without attention to her well-being. At that point Purvi Patel had lost up to 20 percent of her blood and had not passed her placenta after miscarrying the fetus. Petitions to appeal the conviction went out during mass signature campaigns with little impact. I became aware of this historic first-time judgement through social media coverage and blog posts, not mainstream press.

\section{Purvi Patel case details}

Purvi Patel, born in September 1980, managed her father's restaurant, Moe, in Mishawaka, Indiana while living at home with parents and paternal grandparents. She became pregnant from a relationship with a restaurant employee. He was Hispanic and married. Text message exchanges with a close friend show that Patel wanted to end the pregnancy and expressed the desire to purchase abortifacient ${ }^{\mathrm{vi}}$ drugs mifepristone and misoprostol from a pharmacy in Hong Kong with the intent to terminate her pregnancy in June 2013. The fetus and placenta were tested for these drugs whereas none were found (Callahan 2016; Dutt, 2014). On the evening of July 13 , she miscarried the fetus whereas the prosecution believes that she delivered a live baby between 24-30 weeks old. The State charged Patel with class A felony neglect of a dependent, alleging that she failed to provide any medical care to her baby immediately after giving birth causing its death. Patel, then drove to the restaurant after placing the fetus in a paper bag and put the baby in the dumpster near Moe. At this point Patel was bleeding profusely and sensing the need for medical care, drove to the emergency room (Indiana Court of Appeals, 2014). Patel was sentenced to thirty years of imprisonment and ten years were suspended along with a concurrent executed term of six years for feticide. The defense and Patel argued that her neglect of a dependent conviction should be overturned because it is not supported by sufficient evidence. She also argued that the feticide conviction should be overturned as the law is inapplicable and unconstitutional when applied to her as the defendant (Indiana Court of Appeals, 2016).

The courtroom drama was preceded by hospital drama where the chief protagonist with prolife beliefs, Dr. Kelly McGuire, went against the word of his patient and declared that the fetus 
was about 30 weeks and not 10-12 weeks as Patel had previously thought. He even accompanied the police to locate the fetus which he imagined was born alive, again, contrary to what the mother declared. On ultrasound investigation, Patel's uterus was full of blood. This is the court document's clinical way of saying that the loss of blood was significant. After her placenta was surgically removed, the police went in to interrogate her. After the autopsy Dr. Prahlow declared that the fetus was 25 weeks and alive at birth. Patel had already said that the fetus did not cry or show any sign of life. Based upon Dr. Prahlow's autopsy, the State charged Patel with the neglect of a dependent as she had not provided medical care to her baby right after birth. The particular features of Purvi Patel's life continue in detail in the sterile court documents. The level of specificity in the court documents is quite mind boggling, leaving it up to the court process to interpret those details. The minutiae of her life unravel chronologically. Despite the subject matter, the court accounts betray no feelings and no affect. Patel and her family, had no idea what had happened and why until Purvi Patel was incarcerated. They will be searching for answers their whole lives and the courts of law will not help them do that. Growing up in a close extended family, there is no saying how deeply affected Purvi Patel is after returning from jail. After serving almost two years in jail the court decided to vacate Patel's conviction for class A felony and instead convicted her for a class $D$ felony for which she had already served jail time.

\section{Colonial and postcolonial resonance in the Purvi Patel study}

Contemporary dissenting movements such as Black Lives Matter remind us that modernWestern ideals of democracy and justice have not reaped the same gains for AfricanAmerican and indigenous communities as they have for majority European-American White populations (Edwards \& Harris, 2016). This dissent comes from collecting years of precedence from legal, educational, health-related fields by protest leaders, activists, and academics. While the records of South Asian immigration to the United States is historically scantier than other U.S. communities such as African Americans, Latina/o, and the marginalization of Indigenous tribes, I would be amiss in dismissing the intense interactional and overlapping racial histories which have great bearing on the Purvi Patel case.

Social and familial intimacies are politicized in the public sphere, and scholarly attention is being paid to them. Feminist scholars are researching the overlapping of histories of the global, borderlands, the state, and the body (Berlant, 2000, 2004, 2011; Enloe, 1989). The body becomes an important trope to engage as it is vulnerable to control and it is a vehicle of affect and intimacy. Smith believes that "intimacy is an appealing vantage point from which to take on power, geopolitics, and colonial relations. But the collection of intimate data is also one of the mechanisms of colonial power and ongoing state violence" (2016). Just as intimacy can be comforting, it can also be threatening as it can be deployed in the service of state surveillance. Smith (2016) reminds us, recalling work by Stoler (2002) and other anthropologists. As we understand the continuing pattern of assault on the body via legal process and state surveillance, academics must find methods that serve our research purpose and ethics. An autoethnography combines the intense intimacy of the field with critical reflection so as to render a cohesive story of vital assemblages (Pathak, 2010; Ellis et al, 2011; Adams et al, 2015). In pondering what makes autoethnography, decolonial, I am reminded of a classic text by anthropologist Kamala Visweswaran, Fictions in Feminist Ethnography, which underscores that personal stories are important (Visweswaran, 1994). Therefore, to rewrite the vast histories of population control and fertility in story form is important for it becomes more accessible to those who are not demographers and scientists. A decolonial autoethnography must incorporate voices that reflect the deeply personal so as to situate and complexify those voices in the public sphere.

Why is a postcolonial understanding important to the Purvi Patel case as it is for understanding population and fertility control? Postcolonial is not a temporal concept and cannot be seen simply as teleological (Childs \& Williams, 1997). That is, postcolonialism does not just follow colonialism--it presupposes colonialism and reveals it as a hegemonic position that impacts subjects whether in the sphere of politics, education, or the body. Therefore, Purvi Patel, born and brought up in the United States, not during colonial times. Her parents' immigrant status, their sojourn from a recently postcolonial nation-state constructs her as subaltern. She assumes subaltern subjectivity as her voice is muted by first world juridical polemics about women and abortion. A cleavage between classical modern-western positions becomes ossified, namely the Christian Right (pro-Lifers) and the pro-Choice dialectics. This 
modern-western politics wrought in Judeo-Christian tradition has overtaken any other cultural or historical understanding of contemporary life. Postcolonial theory, as rendered by Edward Said and Gayatri Spivak, critically destabilizes intellectual, social, economic received theory. Said (1976) and Spivak (1989) postcolonial theorists, by carefully unfolding the rationale of the colonial project, create a space for previously unheard voices and perspectives, choked by oppressive institutional structures that have remained steadfast since the colonial 'dialectic of master-slave' (Fanon, 1967). Spivak's classic essay, "Can the subaltern speak"(Spivak, 1988) addresses this issue of whose voice is silenced by colonial and postcolonial structures by suggesting that the lowest class members in society suffer a complete loss of social capital. We can recoup certain tropes in this current phase of globalization that has led to a rampant loss of agency among rural communities of the South, whose land is attractive to agro-businesses and their subsistence farming practices are endangered. Globalization however creates a situation where migrants to developed nations are constructed as a unique category of underclass falling even below the domestic working class of the host Western nation. As migrants they do not occupy top positions in technology, education, and medicine but they provide services such as healthcare (nursing, attendants), food service and other forms of domestic labor. Therefore, I want to borrow the idea of subaltern to construct another term of the subaltern migrant who has cosmopolitan credentials but lives in situations-economic, political and cultural, that do not allow them the same status as first world denizens. Spivak does not want Southern academics living in the West to purloin the term, subaltern, such that it loses its potency and meaning.

The circumstances of the study do not allow me to conduct an autoethnography but I am not too far from the main artifact of an ethnography-the story. I am scrutinizing blogs (read below). This praxis takes into consideration Spivak's concern: that it is not easy to give voice to the subaltern because the chosen feminist bloggers are carving a Fraser-ian transnational public sphere by holding their own in a medium that has historically been dominated by males and their concerns.

\section{Literature review on cyberspace as a critical Public Sphere}

Taking up social space (on the web) by writing public statements, access to computers, and possessing the right kind of educational credentials for cyberspace, has traditionally been the exclusive reserve of men (Travers, 2003). That has undergone a change and now white professional women as well as women of color have increasing access. Yet, scholars sense a gap; despite access and academic privilege, many women record being silenced and excluded from important cyber venues such as discussion boards, list serves and web-based discussion of feminist topics (Travers, 2003; Gurak, 2001). Hope is derived from Robbins (1993 in Travers, 2003) who believes that public space continues to get socially constructed, therefore women must continue to evolve modes of social contestation. Other researchers urge feminist scholars to shape the critical nature of the dialogue online (Fraser, 2007; Spender, 1995).

Scholars Steele (2018), Eckert (2018), Duffy (2015) believe in the potential of blogs to nurture dialogue, being a watchdog for mainstream exclusion, creating a space for those politically disenfranchised to maintain public sphere presence. Simply, blogs make the everyday political (Steele, 2018). Each socially marginalized group is participating more on social media and most minority groups have an increasing presence online (Steele, 2018). Scholars such as Duffy (2015) urge us to see all form of feminist digital presence (which I interpret to include feminist blogs) as advancing existing theories of social media production while paying attention to women's lived experiences in the world outside. Eckert's (2018) research on feminist bloggers has surmised that new technologies are important in strategizing and transforming gender relations. She demarcates three kinds of digital feminisms: "street activisms planned via digital media, internet-born movements only constituted on social media, and activisms that fight Internet-related problems" (Sadowski, 2016; in Eckert, 2018). Since the online is forever intertwined with the offline, Eckert borrows from Brophy's (2010) theory of merging the construct of cyberfeminism with liminality to show how women as bloggers are othered while men are seen as the norm. But then access to the internet is through the body and self, therefore a gendered online identity gets created or performed (Brophy, 2010 in Eckert, 2018).

Nancy Fraser in Transnationalizing the Public Sphere, 2014, questions the two core ideas of a deliberative democracy--normative legitimacy and political efficacy, in the formation of a 
critical theory of the public sphere, in a post-Westfalian world where the nation-state has lost its power. The nation-states' loss is the gain of a new world order: transnationalism. Transnationalism is marked by migrant flows, dislocation, re-location while economic, technological and political linkages between people continue to grow (Vertovec, 2009; Glick Schiller, 2005; Grewal \& Kaplan, 2001). These linkages can be positive or negative. Positive, for the scope for greater technological, labor and political linkages and negative, for the immigration debates, for instance, that thinly veil prejudices based upon race, class, nation, sexuality and gender. Fraser who first coined the term subaltern counterpublics gives us expression for an alternate or parallel mode of feminist interaction via cyberspace where feminists and feminist concerns do not just go away but form subaltern counterpublics that carve a resilient space to consolidate a political position. Travers (2003) terms these "mixed" or diverse political spaces as feminist counterpublics.

My interest in the blog posts is due to the fact that they strike a very different note than mainstream press. The bloggers assert their identity as South Asian, and Asian while staking a political claim to cyberspace and to the topic at hand-the politics of reproductive health.

\section{Bloggers' feminist renderings as a Counterpublic}

Nancy Fraser lays store by political participation even if this participation of peers does not amount to equal political citizenship. What is more important to her is a critical public sphere (Fraser, 2007, 1990) that connects with a series of political events that pursue the common good. The three blogs I have chosen to study create a counterpublic focusing on the authors' unique perspective on the issue of reproductive health. The bloggers Nyomi Munaweera, Sharon $\mathrm{H}$. Chang, and Ashwini Tambe respond soon after Purvi Patel is convicted and jailed in Indiana in 2013, harking a new era of biopolitical controls on abortion and reproductive health in the United States.

\section{Blog: Caught between the Misogynies of India and Indiana: The tragic case of Purvi Patel, Nyomi Munaweera}

Munaweera (2015), acknowledges the pressures within South Asian families to remain silent on female "sexuality and desire" which most likely meant that Patel bore the burden of her parents not knowing that she was not a virgin. Nick Patel, Purvi's father is known to have said in the courtroom, that "he raised his daughter and son in a strict Hindu household" (Gray, 2015). He wants to assure the jury that Patel's upbringing is traditional, with an emphasis on modesty. Nick Patel's emphasis on "strict" translates to 'no room for waywardness and premarital sex'. He subtly and unknowingly, distances his daughter and her actions by clearing his name of poor parenting.

In her blog post, Munaweera is able to touch upon unarticulated aspects of South Asian family life that skirt on issues such as unrecognized misogyny, and shame. Munaweera calls out modern (influenced by Modernity and Neoliberalism) mores of gender iniquitous expectations $^{\text {vii }}$ that strips single women in the diaspora of identity and subjectivity, as misogynous. Once named as such, Munaweera mainstreams misogyny within South Asian families. As articulated by Munaweera, misogyny makes South Asian gendered norms recognizable within global norms of gender. After stripping tradition of its veneer of protection, Munaweera exposes the way in which Purvi Patel is treated by the police and legal system as well as her own working class, diasporic community; and her parents and grandparents, migrants from Western India, who most likely took US American citizenship a few decades ago.

The South Bend Tribune reported on January 30, 2015 that Purvi Patel's parents said, "even though they live in a religious home, they would have loved Purvi and her child." The father seems to want to disavow religion and intolerance as the reason why Patel took the actions she did, to dispose of the fetus during the miscarriage. Regardless of the parental testimony, she is sentenced to 20 years in prison. The purveyors of justice-court and jury-understand difference judging from their racially differential sentencing.

Munaweera, at the end of the blog, returns to her leitmotif of misogyny. She ends with, "Patel's story provides a frightening vision of what happens when conservative cultural and political jeopardies rule over women's bodies. Women in both the east and the west continue to be punished by these misogynies" (Munaweera, 2015). The blogpost acknowledges the tricky in-between position a migrant such as Purvi Patel is in ("east and the west") and those of us who believe that reproductive health policies are not made in isolated national 
environments where nation-state is supreme and the global governance and politics of reproductive health does not matter.

\section{Blog: Does it matter that Purvi Patel's baby was mixed-race? Susan H. Chang}

The theme that threads through Sharon Chang's blog post is boundary crossing. Other significant terms she uses to convey the multicultural reality of the arrest are: fences traversed, boundaries, and mixed-race baby. The binaries that Chang addresses are (cis) female/male, married/unmarried, Hindu/non-Hindu, proper/improper, faith/fear, expectation/defiance. Chang (2015) notes that the married co-worker, Purvi Patel's lover, is never questioned but Detective Pelletier interrogates Purvi Patel about him. She bears the burden of disclosing the most intimate aspects of her life including the ethnicity of the lover, whether he was married or not, and if it was a "one-night stand" (Chang, 2015). Right away, histories of religious conservatism and mixed-race orthodoxies emerge in the minds of the authorities, to haunt Purvi Patel.

We are drawn to the corporeal enactments that Purvi Patel is forced to answer questions about. Those are: the body of the fetus, the ethnicity of the lover, her sexual commitments, her religion, all of which are filtered through a taboo culture that ultimately punishes her for transgressing those boundaries. Chang points out: "how women of color, their sexuality and children-sitting at the crossroads of multiple boundaries-are particularly vulnerable in a volatile minefield set up from the start to disadvantage them" (Chang, 2015). Therefore, Purvi Patel's conviction feels more like punishment than the "honor, humanity and dignity of a mother, her loss and her lost mixed-race child" (Chang, 2015). Chang makes a strong case for re-examining social mores and multiculturalism that seems more backward-looking than forward- looking in an economically and politically advanced nation that espouses tolerance, and diversity. The latest census counts people as having multiple races therefore society's response to mixed-race and race/racism cannot be seen as separate (Chang, 2015). Chang urges us to "understand mixed-race from a historical, politically critical and resistant point of view" (2015).

\section{Blog: The Indian feticide case: why Purvi Patel's Indianness matters, Ashwini Tambe}

Tambe (2015) directly refers to the feticide law used to convict Patel, usually employed to seek redress from abusive men -- husbands or boyfriends. Not only is the intentionality of the law reversed but Patel is awarded a hefty sentence. The only two who have fallen prey to this perverted interpretation of reproductive health law are of Indian and Chinese (Bei-Bei Shuai) origin. These are important observations, situating this event within a local and more importantly a global connectedness context, that is beyond simply "international"viii.

Both India and China have had strong programs for population control such that those have created severe socio-political-cultural anomalies within their social fabric. Tambe remembers this political history, delineating in her blog how collective memory of a racialized population control logic is received by the West as normative of life-in-the-developing-world. The students she teaches at a flagship Catholic University, Georgetown, agonize about the West's acceptance (and in the past, funding) of forced sterilizations in India and China but given the Christian evangelical tendencies in how knowledge is produced at the University, feel repulsed by reproductive choice politics in China and India. In their minds, the adoption of population control programs is seen as unilateral decisions by China and India and not as desperate attempt to modernized their societies so they can adopt Bretton Woods inspired neoliberal economic changes.

Moderating this experience is the figure of the "zealous" doctor, Dr. Kelly MacGuire, a member of the American Association of Pro-Life Obstericians who took it upon himself to search for the discarded fetus in a dumpster. These conflicting emotions among students at an elite institution and an overzealous doctor, both parties living in Catholic anti-reproductive health contexts continue to spur me to make connections between the local and the transnational in the Purvi Patel case. The locality of the issue is not enough to understand the seriousness of this legal precedent which has global and transnational ramifications. The political alliances and treaties signed during 1990 United Nation's ICPD, Cairo, get gravely hampered.

\section{Collective theme(s) in the Blogs}

The collective theme(s) in the blog all point to global connections in Purvi Patel's treatment by the state and the legal system. Purvi Patel's immigrant status ("Hyphenation of our 
identities": M), her color/racial status, religion, the history of treatment of non-white women globally and here in the US ("mixed race bodies": C), compel us to examine her as a globally connected citizen living in the throes of a culturally globalized world rather than as just an Indiana resident ${ }^{\mathrm{ix}}$ of color. Tambe's (2015), "China and India serve as poster children in the evangelical crusades [emphasis mine] against abortion", Munaweera's (2015), "women in both the east and west continue to be punished [emphasis mine] by these misogynies" and Chang's (2015) "mixed-race bodies become a stage upon which global politics play out [emphasis mine]." Religion, patriarchy and politics are intricately woven in this verdict making her Hindu identity stand out, due to her family's avowal of being Hindu during the trial, and the evangelical streak present in reproductive health policy.

Tambe brings up a point that Munaweera and Chang briefly allude to. She notes that in the battle over the age and viability of the fetus, there is no concern for the willingness or reluctance of the woman to enter motherhood ("I think we need to renew worries about the creeping ascendance of forced motherhood in the US"). These matters of body and intimacy are becoming aligned with state mechanisms of control, giving rise to an intimate politics and a sharper imperative for a renewed struggle for reproductive rights in the U.S. It is not happenstance that the U.S. has traditionally spent a great deal of time, effort and power to create a foreign policy that places it at the front and center of the abortion, environment, and population management policies around the world (Connelly, 2015; Eager, 2004).

The words of the three blog posts that I have studied are written by women who are linked to Asia and South Asia through birth or parentage. Having been exposed to national, transnational, and differing socio-cultural borders, they are driven to highlight what gets easily missed in unidimensional news reports that parade as objective. These major events in the struggle-based history of global reproductive health take a back-seat in popular press. A much more plural internet-based delivery system raises the concerns of a wider audience and evokes their response and interest.

Twenty years since 1994's ICPD in Cairo ${ }^{x}$, pro-life, pro-eugenicist, pro-control positions have grown and have seeped into our everyday lives without much contest. President Donald Trump's unctuous statement as a Republican presidential candidate about women needing to be punished if they underwent abortion presses the political immediacy of the issue of reproductive health and rights among historically marginalized communities. Campaigns to de-fund Planned Parenthood and the paring of the USAID budget for reproductive health services world wide are other statist attacks on basic reproductive freedoms.

\section{Eugenics: the divergent project of reproductive health}

It is already fabled that Nazi Germany admired the eugenics experiments in the United States and modeled its own forays in this area along those lines. Extraordinary attention was given by scholars and scientists to eugenics in the early part of the twentieth century in the US. "The rush to endorse new ideas seemingly anchored in scientific truth was hardly unusual, and one should not make too much of the early popularity of disparate ideas labeled "eugenic." However, the extraordinary success of proponents of some variety of eugenics in capturing the public's moral imagination cannot be ignored." (Lombardo, 2003, p. 211). The eugenics phase, if anything, reminds us never to take governmental authority, inserted into people's lives through medical intervention, lightly.

Paul Lombardo's research report titled "Taking eugenics seriously: Three generations of ??? are enough?" indicts academics and more specifically specialized branches of science namely genetics as it worked to justify eugenicist tendencies in public policy and the government. Academia was deeply implicated in the promotion of this new branch that promised to ensure the quality of health among the masses. This ideology of achievable perfection had taken such a deep hold of academic research that the flagship journal of the American Genetic Association, The Journal of Heredity, published an introductory article in its first edition authored by scientific luminary Alexander Graham Bell, titled "How to improve the race." Dr. W.C. Rucker, the assistant Surgeon General, is known to have said "eugenics is a science. It is a fact not a fad" (Lombardo, 2003, p.210). A city council candidate from Chicago called himself "the eugenic candidate" and Hellen Keller too publicly favored eugenics' interventions. A sampling of Nobel Laureates' Theodore Roosevelt (1906), Woodrow Wilson (1919), Winston Churchill (1953), Jane Addams (1931), William Shockley (1956), Linus Pauling (1962), Francis Crick (1962), and Gunnar Myrdal (1974) among others advocated eugenics at some point in their career (Lombardo, 2003). The prospect for a perfect society 
compelled top scientists, social workers, intellectuals and politicians to favor a eugenicist ideology. The question we need to ask is how can this thinking from the early part of last century overlap with measures today? When Governor Mark Warner in Virginia offered a public apology for the state's eugenicist policies, some citizens protested saying that at the time the offences were meted, sterilizations were still legal. Lynchburg, Virginia houses the site for the institution known as the Virginia Colony for Epileptic and Feebleminded. In all, about 60,000 Americans were sterilized in the first 70 years of last century but none were compensated (Lombardo, 2003). When state control parades as good science, we are reminded of Foucauldian theorizations of power or a specific governmentality that emerges at the confluence of technologies of self and technologies of power. The state then governs persons in this absolutist manner manipulating the juridical tenets of the land. While the discourse of population control was never stated as eugenicist, its tendency, in the implementation of family planning programs took a darkly eugenic-centered approach. The adoption of fertility control programs in postcolonial nation-states and developing countries over half a century has given us a unique perspective on the efficacy and ethics of population planning.

\section{Globality and transnationalism in population discourse: A keener look into the present}

The philosophy and global strategy of population control overcame planning in several parts of the world as territorial colonization was dismantling. The discourses that emerged in newly formed nation-states during the post-colonial period assumed power dynamics reminiscent of colonial times. Today on the other hand, there is no overt talk of colonization or population control but both these institutions and discourses manifest themselves as public anxieties. These anxieties surface when there is talk of food shortages, hunger, war, and of course, environmental decay. Our normalized response lays quick blame on a veritable population explosion. Paul Ehrlich's 1968 publication The Population Bomb allowed the predictions of doom and decay as a natural outcome of untamed female fertility. Foucault reminds us that population as an idea and as a reality is decidedly modern (Foucault, 2007). Layered on to these modern-Western and neoliberal urban anxieties is Climate Change which makes the understanding of population more dire than it is, especially in the way it relates to Foucauldian governmentality (in specific biopower) and political power. Population becomes a concern about numbers-who has more and whom, less. The fact that the population in India has risen to almost match the 1.25 billion persons in China gives rise to deep concern among planners and politicians in the West.

\section{Population Discourse as Anxiety, Climate Discourse as Possibility}

I argue here that setting up a context for studying the legacies of reproductive health globally offers the possibility of greater inter-disciplinarity in Communication, feminist theory, international development, and human rights, so as to center debates connected with women, state and biopolitical control alive within academia and the grassroots. I argue further that the material conditions of indigenous, poor and marginalized populations in the two global hemispheres have different contexts but very similar terms of regulatory and repressive treatment. In spite of this, at the heels of a game changing paradigm such as Climate Change, and the talks in Paris in 2015, we are offered the possibility of new political, grassroots alliances and convergences that were hitherto not envisaged. Whereas reproductive health laws and policy have seen progress globally, these policies have often resulted in uneven gains among marginalized and poor women domestically and around the world. Whereas globalization and transnationalism have provided us theoretical frames to understand capital and cultural flows, even so, the excesses of the dominant paradigm of population control are rarely seen as an outcome of policies external to a specific nation-state. The terms de-colonial and postcolonial must maintain connection and currency because they allow us to solidly establish historicity and temporality in the struggles connected with reproductive health. Postcolonial populations in the Global South and indigenous, marginalized, immigrant and sexual minority populations in the Global North find access to health centers and to reproductive justice discourses. I believe that we have inched slowly away from Malthusian logics about the earth's finite resources. The panic caused by Malthus' theory of population was temporarily revived by the population control movement in the 60 s and 70 s, and actively resisted by civil society especially during ICPD Cairo 1994 (see an earlier endnote). The Paris Talks have shed renewed light upon population discourse and reframed it to fit the logic of climate change and environment. In this way, population discourse becomes part of a larger 
rationale for a healthy and equitable world.

The Climate Change era is in essence coming full circle, reminding the global public of inextricable links between the natural environment, socio-economic ground realities and human fertility. The International Planned Parenthood tweets from the Paris Conference expressed enthusiasm for advocating reproductive rights, and a desire to initiate a conversation on "climate resilient communities" (IPPF, 2015). This positive framing of discrete communities brings us closer to a kinder future vision where North and South denizens enjoy equitable access to reproductive health. All too often, after large UN conferences, we have seen a falling flat of political will even when charters are ratified with global witnesses and civil society, amidst great fanfare and sound policy blueprints.

What might environment and climate change policies mean in an age when tubal ligation surgeries are still peddled as contraception and where mandatory family size, birth control and abortion are dictated by the state? The economic and socio-cultural gains of globalization have proved to be inequitable in most regions of the world, which is another reason why frameworks of decolonization and post-colonialism cannot be forgotten just yet. What does it take to create climate resilient communities called forth by civil society in Paris in November 2015? It remains to be seen how climate change deliberations and the post Paris era will determine the course of reproductive health globally.

\section{Population as National Security: Cases of India, China and the United States}

The cases of three countries: The United States, India and China provide grist for the mill in population debates. Namely, China and India have pursued aggressive population regulation and control policies for several decades, while the U.S. has led the policy and funding decisions globally.

China: China instituted its one-child policy in 1979, and what was initially meant to be a one generation-long policy stayed in place for 35 years. Since 1980, China is known to have collected fines to the tune of 2 trillion yuan ( $\$ 320$ billion) from parents who chose to violate the strict policy of birthing one child (Minter, 2014). The other option for violating families was forced abortion. Government sources in China say that 400 million births were prevented though many scholars counter the claim due to the unquantifiable impact of the policy on psychological and sociological dynamics in the country. This policy has now been changed to a two-child policy since the close of 2015 . To civil society, that still qualifies as control. India's experience is different.

India: India was the first nation to institute a population control policy in 1951-52 during the formulation of their first five-year plans, a postcolonial nation free from British colonialism in 1947. India's policies came under scrutiny for the overzealousness of the Government in the 1970s, 80s and 90s to include sterilization and money incentives in an effort to meet quotas for tightly controlled state programs euphemistically known as family planning. Family Planning gained particular notoriety during the National Emergency Period in 1976-1977 when the Prime Minister, Indira Gandhi, used coercive strategies to sterilize men. This period was marked by numerous political overindulgences, but male sterilization remained emblazoned in public memory. Later, policies focused on female sterilization and received less of an outcry until the feminist movement and civil society agitated for impacting the paradigmatic shift from population contro/ to women's health and reproductive health in the mid-1990s.

United States as global leader: Population policies have been part of national security policy (in the US since 1970s) and define North-South relations, just as other concerns namely immigration, refugees, food sustainability and war (Connelly, 2003). The United States funded the UNFPA (United Nations Population Fund) until the 1980s so it could sponsor fertility control programs in several parts of the world and establish its leadership in the realm of global population policy. Later, the US divested from the UNFPA. Jesse Helms, a Republican Senator from North Carolina, introduced an amendment to the US Foreign Assistance Act thereby banning all US support for abortion services. United States' relations with UNFPA (United Nations Fund for Population Activities) were severed as UNFPA advocates against all unwanted pregnancies, and advocates comprehensive reproductive health care ${ }^{\mathrm{xi}}$.

US national security policy has relied upon maintaining a leadership role in global population policy since the 1970s (Eager, 2004). For the most part, the US and European superpowers succeeded in persuading countries in the global South to adopt programs for fertility control leading to initiatives often called Family Planning or given other friendly terms 
such as Family Welfare. Postcolonial countries themselves sought programmatic and funding support from the West, especially from the United States, the largest funder of global population policies until the mid-80s. In addition, several Western Foundations and Universities supported family planning initiatives (Connelly, 2004). While civil society advocates of reproductive rights are aware of the history of fertility control directives, qualitative inquiries in postcolonial contexts, caution us that there has not been a complete reversal of population control strategies that often collapse reproductive health, and child and maternal health programs at the grassroots levels (Abrejo et al, 2008). The unexamined narratives of population control over decades have created a culture of control among bureaucracies connected to family planning. Eager asserts, "the population control establishment worked multilaterally and bilaterally to demonstrate and persuade developing countries that it was in their national interest to undertake family planning programs" (Eager, 2004).

\section{In the End}

Situating the Purvi Patel abortion saga tainted with the legacies of colonial thought, postcolonial resonances, and first world prejudice, I am heartened to hear of her release from state confinement. She still remains burdened by the charge of neglect of a dependent and the felony charge (Felony A to D). The felony charge though reduced has not been eliminated from her record. It does not take very much to register a forbidden intimacy in a policed multi-racial society. One just has to cross the borders of family, caste, nationality, race, ethnicity or gender for socio-political warnings to light up. Intimacy, sexuality, and reproductive choices must not find their death knell in any form of social censure. Purvi Patel must now bear the weight of her decisions and try to find a way to heal the emotional and physical scars of her encounter with US American legal commandments. Added to that, her wish to remain a private citizen is abrogated and her life remains exposed for all to comment and judge. A Judeo-Christian understanding of abortion is thrust upon her consciousness adding to her "guilt." Legal actions are perceived as neutral or secular but they are given birth to in religious subjectivity and impinge upon disparate religious contexts. It is not insignificant that the grand opening of a creation museum (known as "young earth" creationism) in Kentucky, with a \$102 million display of the "ark encounter" is an outward manifestation of religious nationalism sweeping the country, making Christianity an important interpretive framework in civilian life (Goodstein, 2016).

This offering of interpretation of media coverage, and of political markers (eugenics era, the population control paradigm), argues that reproductive health harks a significant moment in global politics, feminist histories, and grassroots human rights discourse. This issue has become a struggle about who has a right to survive, share, and become heir to the earth. The national and global political climate thrusts us in a historical time period demanding citizen attentiveness about legal and policy documents placing women's reproductive rights in peril. Through recent human history, female reproduction has been mediated by male administrators $^{\text {xii }}$ of Western Governments and Foundations upholding Western modernity and neoliberalism. While there is a greater push for multilateral cooperation between North and South nation-states, clear lines are drawn, as in global medical interventions (policies) that are based upon traditional markers of power maintenance as during colonial times. Despite the fraught practice of reproductive diplomacy that almost immediately replaced colonial policies, the Purvi Patel case demonstrates that the locus of struggle remains the woman's body and her ability to reproduce.

Postcolonial figures such as Gayatri Spivak begs to believe, and I agree, that the subaltern cannot speak. This study excavates value in modern digital technologies as a start. Blogs seize the public sphere, rather than be invited, in the form of transnational feminist counter publics to give us critique and voice even as the reproductive health war is waged on women's bodies.

Endnotes

i. "The 7th U.S. Circuit Court of Appeals in Chicago has ruled an Indiana abortion ban signed into law by then-Gov. Mike Pence in 2016 unconstitutional. The law would prevent women from having abortions based on the gender, race, or disability of the fetus" (McCarter, 2018).

ii. Texas has instituted this law and has recently, in 2017 , incarcerated a woman desiring abortion services. The woman is 
considered an unaccompanied immigrant minor https://www.aclu.org/news/aclu-court-fight-federal-officials-blockingyoung-womans-abortion-texas; Ohio has recently banned abortion if fetus is six week or over. Ohio also bans insurance coverage of abortion for women who have undergone rape or incest.

iii. Not only was Purvi Patel treated as a criminal and not a patient but her parent's house too was searched for evidence in the wee hours of the morning. The South Bend Review from Jan 30 says: "They [parents in court] both became emotional when discussing being forced to leave their home early in the morning of July 14, 2013, as investigators searched for evidence. They along with Nick Patel's parents, both of whom are in their 90s, were all forced to leave during the search" (Gray 2015).

iv. Such as the Nirbhaya rape in New Delhi; sterilizations in India and China, the persistent questioning by Detective Pelletier of Patel's lover's ethnicity/nationality, and the continued leadership of Population control by the US (Eager, 2004).

v. Forced motherhood is alluded to repeatedly in feminist literature and in the select blogs I have examined; and fetal personhood is understood as strictly far right pro-life agenda. The pregnant woman then has fewer rights than the fetus.

vi. The term abortifacient is contested in women's history. Stassa Edwards (18 November 2014) in The History of Abortifacients (http://jezebel.com/the-history-of-abortifacients-1658993381) writes, "the history of abortifacients is a narrative that parallels and informs our own contemporary debates over them, particularly in the wake of the Hobby Lobby decision [landmark Supreme court decision Burwell vs. Hobby Lobby]. It's a history that has always been mired in the murky waters of what exactly an abortifacient is; what constitutes life, and when does it begin? But it is also a story of the incredible flexibility of legal systems that found ever-new and astonishing ways to suppress reproductive freedom."

vii. Gender iniquitous expectations such as 'no-sex' before marriage, or living/growing up, even after attaining adulthood, in a maternal joint family before marriage, and then in the husband's extended family home after marriage. This is a common expectation of women rather than men.

viii. "Inter-national" presupposes that two nation-states are in conversation. The academic turn to adopt new language-transnationalism and globalism changes the paradigm to include other forms of partnerships, relationship and organizational structures; other than the formerly plenipotentiary nation-state.

ix. Although being an Indiana resident is important in the Purvi Patel case because Indiana, while Mike Pence was still the Governor, set the pace for subjugating women involved in abortion cases.

x. Almost 20 years back, in 1994, the ICPD in Cairo became a landmark conference because it allowed feminist civil society to provide a perspective most in line with women's rights. This move to allow non-government organizations a place on the table along with nation-states changed the politics of reproductive health forever. Pro-life groups were also given similar autonomy therefore one unintended outcome of ICPD is the rise of the legitimacy of pro-life politics in the global sphere.

xi. However, there was a radical shift worldwide in national policies and grassroots implementation of family planning after ICPD Cairo, where feminist civil society groups questioned the imperiousness and exclusivity of government-togovernment dialogues behind closed doors. Unlikely emergent grassroots groups such as the pro-life activists also gained equal ground in Cairo . At the ICPD (International Conference on Population and Development) conferences in Mexico in 1984 and Cairo in 1994, the US joined hands with Latin American countries, El Salvador, Honduras, Dominican Republic, and Haiti in opposing abortion. The pro-life lobby evolved into a non-state actor at ICPD Cairo in 1994. As it stands today, the issue of abortion and reproductive rights is highly politicized (Solinger, 2013).

xii. Nafis Sadiq, a prominent feminist and Pakistani gynecologist was made the head of United Nations Fund for Population Activities in 1987 but by the time she assumed leadership, US had already divested from the UNFPA. 


\section{References}

Abrejo, F.G., Shaikh, B.T., Saleem, S. (2008). ICPD to MDGs: Missing links and common grounds. Reproductive Health, 5 (4), 1-8.

Adams, T.E., Jones, S. H., Ellis, C. (2015). Autoethnography: Understanding qualitative research. Oxford, UK: Oxford University Press.

Andrusko, D. (2016). Indiana Court of Appeals overturns feticide conviction against Purvi Patel. National Right to Life News,34.

Author. (2018). XXXX. Encyclopedia of Intercultural Communication. Blackwell Wiley Publishers.

Author. (2017). XXXX. Women's Studies International Forum. 60(1), 58-68.

Babu, C. (2015). This has NEVER happened before. India Abroad, pp. A5-A6.

Bazelton, E. (2015). Purvi Patel could just be the beginning. New York, NY: New York Times Magazine.

Berlant, L. (2011). Cruel Optimism. California, CL: Duke University Press.

Berlant, L. (2000). Intimacy. Chicago, IL: University of Chicago Press.

Bhatia, R. (2016). A reproductive justice perspective on the Purvi Patel case. Indian Journal of Medical Ethics, 1(4), 249-253.

Burke, J. (2014). Indian women die after state-run mass sterilisation campaign goes wrong. [Web log post] Retrieved from http://www.theguardian.com/world/2014/nov/11/indian-women-die-mass-sterilisationcamp

Callahan, R. (2016). Purvi Patel's Appeal of Feticide Conviction Goes to Indiana Court. India - West, p. A18.

Chakrabarty, D. (2008). Provincializing Europe: Postcolonial thought and historical difference. Princeton, $\mathrm{NJ}$ : Princeton University Press.

Chang, S. (2015). Does it matter that Purvi Patel's baby was mixed-race?[Web log post] Retrieved from http://multiasianfamilies.blogspot.com/2015/04/does-it-matter-that-purvi-patels-baby.html

Charmaz, K. \& Belgrave, L. L. (2015). Grounded Theory. The Blackwell Encyclopedia of Sociology. DOI: 10.1002/9781405165518.

Chatterjee, N., \& Riley, N. (2001). Planning an Indian modernity: The gendered politics of fertility control. Signs, 26(3), 811-845.

Childs, P. \& Williams, R. J. P. (1997). An Introduction to Post-Colonial Theory. London: Prentice Hall.

Connelly, M. (2003). Population control is history: New perspectives on the international campaign to limit population growth. Society for Comparative Study of Society and History.45(1), 122-147.

Connelly, M. (2006). Population control in India: Prologue to the emergency period. Population and Development Review, 32(4), 629-667.

Duffy, B.E. (2015). Gendering the Labor of Social Media Production. Feminist Media Studies, 15(4), 710-714.

Dutt, E. (2014). The Uncertain Guilt of Purvi Patel. News India - Times, p. 5,15.

Dutt, E. (2015). Villain or Victim? News India - Times, pp. 5-6.

Dutt, E. (2016). Indiana Appeals Court Overturns Conviction Of Purvi Patel. News India - Times, p. 13.

Eager, P.W. (2004). Global Population Policy: From population control to reproductive rights. Wiltshire, UK: Ashgate

Eckert, S. (2017). Fighting for recognition: Online abuse of women bloggers in Germany, Switzerland, the United Kingdom, and the United States. New Media and Society, 20(4), 1282-1302.

Edwards, S.B. \& Harris, D. (2016). Black Lives Matter. Essential Library, Abdo Publishing.

Edwards, S. (2014). The History of Abortifacients. Retrieved from: http://jezebel.com/the-history-ofabortifacients-1658993381

Enloe, C. (1989). Bananas, beaches and bases: Making feminist sense of international politics. London: Pandora Books. 
Fanon, F. (1952). Black Skin, White Masks (trans Richard Philcox). New York: Grove Press.

Fleming, M. B. (2008). Feticide laws: Contemporary legal applications and constitutional inquiries. Pace Law Review, 29(1), 43-74.

Flavin, J. (2013). Arrests of and Forced Interventions on Pregnant Women in the United States, 19732005: Implications for Women's Legal Status and Public Health. Journal of Health Politics, Policy and Law, 38(2), 299-343.

Fowler, R. (2015). Purvi Patel's conviction is a travesty against women. Retrieved from: http://alj.am /1D0zYxG

Fraser, N. (1990). Rethinking the public sphere: A contribution to the critique of actually existing democracy. Social Text, 25-26, 56-80.

Fraser, N. (2007). Transnationalizing the Public Sphere: On the legitimacy and efficacy of public opinion in a post-Westphalian world. Theory, Culture \& Society, 24(4), 7-30.

Gandhi, A. (2016, June 03). WHY PURVI PATEL'S CASE IS A WARNING TO WOMEN IN 38 STATES. India Abroad, pp. A16-A17.

Gastelum, A. (2015). Purvi Patel's legal team attacks evidence behind her controversial conviction for feticide, child neglect. Retrieved from: https://www.pri.org/stories/2015-10-02/purvi-patels-new-defense team-appeals-her-conviction-feticide-and-child-neglect

Goodstein, L. (2016). A Noah's Ark in Kentucky, dinosaurs included. Retrieved from: https://www.nytimes .com/2016/06/26/us/noahs-ark-creationism-ken-ham.html? r=0 Indiana Court of Appeals. (2016). Opinion 71A04-1504-CR-166.2016.

Glick Schiller, N. (2005). Transnational social fields and imperialism: Bringing a theory of power to transnational studies. Anthropological Theory, 5(4), 439-461.

Grewal, I.. \&Kaplan, C. (2001). Global Identities: Theorizing transnational studies of sexuality. GLQ: A Journal of Lesbian and Gay Studies, 7(4), 663-679.

Gurak, L. (2001). Cyberliteracy: Navigating the Internet with awareness. New Haven, CT: Yale University Press.

IPPF (International Planned Parenthood Federation). (2015, December 1). Climate Change and reproductive health. [Web log post] Retrieved from http://www.ippf.org/news/blogs/Climate-change-andreproductive-health

Iyer, D. (2015). 'I REMEMBER HOW MARGINALIZED I OFTEN FELT IN SOUTH BEND, INDIANA'. India Abroad, p. A9.

Karkal, M. (1994). Why the Cairo document is flawed. Third World Resurgence, 50 (19) 19-24.

Knight Steele, C. (2018). Black bloggers and their varied publics: The everyday politics of Black discourse online. Television and New Media, 19(2), 112-127.

Kristof, N. (2008). Birth control for others. Sunday Book Review. The New York Times.

Lombardo, P. A. (2003). Taking Eugenics seriously: Three generations of ??? are enough? Florida State University Law Review, 30, 191-218.

Mans, Lori K. (2004). Liability for the death of a fetus: Fetal rights or women's rights? University of Florida Journal of Law and Public Policy, 15(2), 295-312.

McCarter, J. (2018). Mike Pence's Indiana abortion law declared unconstitutional. Retrieved from:https://www.dailykos.com/stories/2018/4/20/1758721/-Mike-Pence-s-Indiana-abortion-lawdeclared-unconstitutional

Mohanty, C. T. (1991). Under Western eyes: Feminist scholarship and colonial discourses. In Third world women and the politics of feminism, edited by C.T. Mohanty, A. Russo, and L. Torres, pp. 51-80. Bloomington: Indiana University Press.

Minter, A. (2014). The Real End of China's One-Child Policy. [Web log post] Retrieved from:http://www.bloombergview.com/articles/2014-04-02/the-real-end-of-china-s-one-child-policy

Munaweera, N. (2015). Caught between the misogynies of India and Indiana: The tragic case of Purvi Patel. [Web log post]. Retrieved from:http://www.huffingtonpost.com/nayomi-munaweera/caught-between-themisogynies-of-india-and-indiana_b_7021766.html

Nagar, R. (2002). Footloose researchers, 'traveling' theories, and the politics of transnational feminist praxis. Gender, place and culture: Ajournal of Feminist Geography, 9, 179-186. 
Nagar, R. \& Geiger, S. (2007). Reflexivity and positionality in feminist fieldwork revisited. In Politics and practice in economic geography, edited by A. Tickell, E. Sheppard, J. Peck and T. Barnes, pp.267-278. London: Sage.

Pathak, A. (2010). Opening my voice, claiming my space: Theorizing the possibilities of postcolonial approaches to autoethnography. Journal of Research Practice, 6(1), M10, 1-12.

Peterson, M. (2015) Patel will not testify in child neglect trial. [Web news post] Retrieved from http://www.wndu.com/home/headlines/Patel-will-not-testify-in-child-neglect-trial-290377071.html

Rajendran, P. (2016). Feticide conviction in Purvi Patel case overturned. India Abroad, p. A14.

Reynolds, D. (2002). Oregon Governor apologizes for eugenics “misdeeds," Inclusion Daily Express.

Robbins, B., (Ed.). (1993). The Phantom Public Sphere. Minneapolis: University of Minnesota Press.

Said, E. (1975). Orientalism. Verso Books.

Salzillo, L. (2015). Catholic nun explains Pro-Life in a way that will stun many (Especially Republican Lawmakers). Daily Kos. Retrievedfrom https://www.dailykos.com/stories/2015/07/30/1407166/-CatholicNun-Explains-Pro-Life-In-A-Way-That-May-Stun-The-Masses?detail=emailclassic

Smith, S. (2016). Intimacy and angst in the field. Gender, Place and Culture, 23(1), 134-146.

Solinger, R. (2013). Reproductive Politics: What everyone needs to know. Oxford: Oxford University Press.

Sohrabji, S. (2015, May 08). Purvi Patel, Convicted of Killing Fetus, Appeals 20-Year Prison Term. India West, p. A20.

Spender, D. (1995). Nattering on the Net: Women, Power and Cyberspace. Toronto: Gramond Press.

Spivak, G. C. (1988). Can the subaltern speak? In Marxism and the Interpretation of Culture, pp. 271-313. UK: Macmillan Education.

Stoler, A. L. (2010). Carnal knowledge and imperial power: Race and the intimate in colonial rule, Second Edition. Berkeley: University of California Press.

Team, S. (2015). Fund raises $\$ 20,000$ for Purvi Patel's family and legal defense. Retrieved from http://www.thesouthasiantimes.info/news-Fund_raises_\$20000_for_Purvi_Patel\% E2\%80\% 99s_family_and_legal_defense-92973-New\%20York-112.html

Tomlinson, J. (1994). A Phenomenology of Globalization? Giddens on Global Modernity. European Journal of Communication, 9(2), 149-172.

Travers, A. (2003). Parallel subaltern counterpublics in cyberspace. Sociological Perspectives, 46 (2), 223-237.

Vertovec, S. (2009). Transnationalism. Abingdon: Routledge.

Visweswaran, K. (1994). Fictions of feminist ethnography. Minneapolis: University of Minnesota Press.

Yeung, M. (2015). How Asian American Women Became The Target OfAnti-abortion Activism. News India Times, p. 7. 